\title{
Interleukin-31 stimulates production of inflammatory mediators from human colonic subepithelial myofibroblasts
}

\author{
YUHKI YAGI $^{1}$, AKIRA ANDOH $^{1}$, ATSUSHI NISHIDA $^{1}$, MAKOTO SHIOYA $^{1}$, TAKASHI NISHIMURA ${ }^{1}$, \\ TAKAYOSHI HASHIMOTO ${ }^{1}$, TOMOYUKI TSUJIKAWA ${ }^{1}$, YASUHARU SAITO ${ }^{2}$ and YOSHIHIDE FUJIYAMA $^{1}$ \\ ${ }^{1}$ Department of Internal Medicine, ${ }^{2}$ Division of Gastrointestinal Endoscopy, \\ Shiga University of Medical Science, Seta-Tukinowa, Otsu, Japan
}

Received January 30, 2007; Accepted March 8, 2007

\begin{abstract}
Interleukin (IL)-31 is mainly produced by CD4+ $\mathrm{T}$ cells, in particular $\mathrm{T}$ cells skewed toward a Th2 phenotype. Here we report for the first time that IL-31 stimulates secretion of proinflammatory cytokines, chemokines and matrix metalloproteinases (MMPs) from human colonic subepithelial myofibroblasts (SEMFs). The effects of IL-31 were investigated by cDNA microarrays, enzyme-linked immunosorbent assay, and real-time PCR. IL-31 effectively induced chemokines [IL-8, GRO- $\alpha$ (growth-related oncogene- $\alpha$ ), MCP-3 (monocyte chemoattractant protein-3), CXCL3, CCL13 and CCL15], proinflammatory cytokines (IL-6, IL-16 and IL-32) and matrix metalloproteinases (MMP-1, MMP-3, MMP-25 and MMP-7). IL-31 dose-dependently induced secretion of IL-6, IL-8, GRO- $\alpha$, MCP-3, MMP-1 and MMP-3. The effects of IL-31 were comparable to the effects of IL-17A. IL-31 and IL-17A showed additive effects on IL-6, IL-8, GRO- $\alpha$, MCP-3, MMP-1 and MMP-3 secretion. In conclusion, we demonstrated that IL-31 is a potent inducer of proinflammatory mediators in human colonic SEMFs. IL-31 may function as a proinflammatory cytokine derived from Th2 cells.
\end{abstract}

\section{Introduction}

Ulcerative colitis (UC) and Crohn's disease (CD), two common forms of idiopathic inflammatory bowel disease (IBD), are chronic, relapsing inflammatory disorders of the gastro-

Correspondence to: Dr Akira Andoh, Department of Internal Medicine, Shiga University of Medical Science, Seta-Tukinowa, Otsu 520-2192, Japan

E-mail: andoh@belle.shiga-med.ac.jp

Abbreviations: IBD, inflammatory bowel disease; IL, interleukin; GRO, growth-related oncogene; MCP, monocyte chemoattractant protein; MMP, matrix-metalloproteinase; SEMF, subepithelial myofibroblast; ELISA, enzyme-linked immunosorbent assay; RTPCR, reverse-transcription polymerase chain reaction

Key words: interleukin-31, inflammatory mediators, colonic myofibroblasts intestinal tracts. Although the precise etiology of IBD remains unclear, a widely accepted hypothesis is that ubiquitous, commensal intestinal bacteria trigger an inappropriate, overactive, and ongoing mucosal immune response that mediates intestinal tissue damage in genetically susceptible individuals (1-3).

Recently, a novel cytokine, interleukin (IL)-31, was cloned and found to be produced mainly by $\mathrm{CD}^{+} \mathrm{T}$ cells $(4)$, in particular by skin-homing $\mathrm{CD}_{45 \mathrm{RO}^{+}}$(memory) $\mathrm{T}$ cells. Transgenic mice overexpressing IL-31 either with a lymphocyte-specific promoter or a ubiquitous promoter experienced a skin phenotype closely resembling atopic dermatitis in human subjects (4). Notably, in mice IL-31 seems to be preferably produced by $\mathrm{T}$ cells skewed toward a Th2 phenotype; however, Th1-skewed T cells also produce substantial amounts of IL-31 (4). IL-31 mRNA expression is widely detectable in various organs, including the gastrointestinal tracts (4).

IL-31 is most closely related to the family of IL-6-type cytokines known to be involved in many immunomodulatory functions, particularly the acute-phase response, but also in the proliferation of B and T cells (5). However, IL-31 is clearly distinct from IL-6-type cytokines because it does not signal through glycoprotein-130 (GP-130), the common signaling receptor subunit. IL-31 uses a previously described orphan receptor, the glycoprotein 130-like monocyte receptor or glycoprotein 130-like receptor (GPL) (6), in combination with the oncostatin M receptor (OSMR) (4). Nevertheless, cellular responses induced by IL-31 remain unclear in all cell types.

Human colonic subepithelial myofibroblasts (SEMFs) are present immediately subjacent to the basement membrane in normal intestinal mucosa, juxtaposed against the bottom of epithelial cells $(7,8)$. Colonic SEMFs play a role in inflammation and wound healing in the intestine (7-10). Here we report for the first time that IL-31 stimulates secretion of proinflammatory cytokines, chemokines and matrix metalloproteinases (MMPs) in human colonic SEMFs, suggesting a role of IL-31 in the pathophysiology of IBD.

\section{Materials and methods}

Reagents. Recombinant human IL-31 and IL-17A were obtained from Pepro Tech (Rocky Hill, NJ). 
The isolation and culturing of human colonic SEMFs. Primary human colonic SEMFs were prepared according to a method described in our previous report (11). Cells were cultured in DMEM containing 10\% FBS, $50 \mathrm{U} / \mathrm{ml}$ penicillin and $50 \mu \mathrm{g} / \mathrm{ml}$ streptomycin. Studies were performed on passage 3-6 SEMFs isolated from four surgically resected samples.

Quantification of human cytokines, chemokines and MMPs. Amounts of antigenic IL-6 and IL-8 in the samples were determined by sandwich ELISA kits purchased from BioSource (Camarillo, CA). The ELISA kit for matrix metalloproteinase (MMP)-1 was purchased from Amersham (Piscataway, NJ), MMP-3 was purchased from Daiichi Pure Chemicals Co., Ltd. (Tokyo, Japan), and that for GRO- $\alpha$ and MCP-3 was purchased from R\&D systems (Minneapolis, $\mathrm{MN})$.

Chip hybridization. The total cellular RNA ( $4 \mu \mathrm{g})$ extracted from human colonic SEMFs was converted to double-strand cDNA with a double-strand cDNA synthesis kit (Invitrogen) and oligo(dT) primers containing a T7 RNA polymerase promoter (Takara-Bio, Kyoto, Japan). Cy3- and Cy5-labeled cRNAs were generated from cDNA samples by transcription with T7 RNA polymerase (Takara-Bio). Samples obtained from non-stimulated SEMFs were labeled with $\mathrm{Cy} 3$, and samples from cells stimulated with IL-31 for $6 \mathrm{~h}$ were labeled with Cy5.

We employed an IntelliGene HS human expression chip (Takara-Bio), which includes $\sim 16,000$ characterized sequences based on the human NCBI reference data. Cy3and Cy5-labeled cRNA probes were mixed and hybridized under the following conditions: (6X SSC, $0.2 \%$ SDS, $5 \mathrm{X}$ Denhardt's solution, $50 \%$ formamide) at $70^{\circ} \mathrm{C}$ for $14 \mathrm{~h}$. Chips were scanned with an Affymetrix 428 array scanner (Santa Clara, CA). Data analyses were performed using BioDiscovery ImaGene ver. 4.2 (El Segundo, CA). For data analyses, globallowess normalizations were performed (12).

Reverse transcription-polymerase chain reaction (RT-PCR). Total cellular RNA was isolated by the acid guanidinium thiocyanate-phenol-chloroform method (13). RT-PCR analyses were performed according to a method described in our previous report (14). PCR products were ligated into TA cloning vectors (Promega, Madison, WI) and sequenced. Primers specific for human cytokines, chemokines and MMPs were as follows: human IL-6, 5'TGAGAAAGGAGACA TGTAAC (nucleotides 262-282, Gene bank accession no. 000600) and 3'AGTGTCCTAACGCTCATACT (824-803); human IL-8, 5'ACATGACTTCCAAGCTGGCC (nucleotides 101-121, Gene bank accession no. 000584) (15) and 3'TTT TATGAATTCTCAGCCCT (404-385); human MMP-1, 5'A GATTTGCCAAGAGCAGATGT (nucleotides 437-458, Gene bank accession no. 002421) and 3'TCCATATATGGC TTGGATGCC (852-831); human MMP-3, 5'AACCTTTCC TGGCATCCCGAA (nucleotides 303-323, Gene bank accession no. 002422) and 3'CAGCCAACTGTGATC CTGCTT (880-860); human GRO- $\alpha$, 5'CTCTTCCGCTCCT CTCACAG (nucleotides 35-54, Gene bank accession no. 001511) and 3'CACCAGTGAGCTTCCTCCTC (431-412); and human MCP-3, 5'ACCACCAGTAGCCACTGTCC (nucleotides 230-249, Gene bank accession no. 006273) and 3'TTCAAAACCCACCAAAATCC (581-562). Real-time PCR was performed using LightCycler 2.0 system (Roche Applied Science, Tokyo, Japan) with specific primers as described above. PCR was conducted using a SYBR-Green PCR Master mix (Applied Biosystems, Foster city, CA). Data were normalized versus $B$-actin for human IL-31.

Statistical analyses. Data are expressed as means \pm SD. Statistical significance of changes was determined by the Mann-Whitney $\mathrm{U}$ test. Differences resulting in $\mathrm{P}$ values $<0.05$ were considered to be statistically significant.

\section{Results}

Microarray analyses of colonic SEMFs with IL-31. To define the role of IL-31 in the intestinal mucosa, we investigated how IL-31 modulates mRNA expression in human colonic subepithelial myofibroblasts (SEMFs). For this purpose, we engaged cDNA microarrays. Judging by the criteria of a $>3$ fold increase, the expression of 20 genes was altered by IL-31 stimulation (500 ng/ml, 12 h) (Table I). Each of three independent examinations demonstrated that IL-31 effectively induced chemokines [CXCL8 (IL-8), CXCL1 (growthrelated oncogene; GRO- $\alpha$ ), CCL7 (monocyte chemo-

Table I. IL-31-induced genes in human colonic myofibroblasts.

\begin{tabular}{|c|c|c|}
\hline Gene name & $\begin{array}{l}\text { NCBI reference } \\
\text { sequence ID }\end{array}$ & $\begin{array}{c}\text { Fold change } \\
\text { value }\end{array}$ \\
\hline CXCL8 (IL-8) & NM_000584.2 & 24.67 \\
\hline CXCL1 (GRO- $\alpha)$ & NM_001511.1 & 21.39 \\
\hline CCL7 (MCP-3) & NM_006273.2 & 18.15 \\
\hline MMP-3 & NM_002422.2 & 14.63 \\
\hline MMP-1 & NM_004142.1 & 12.92 \\
\hline Toll-like receptor 8 & NM_016610.2 & 10.78 \\
\hline CXCL3 (GRO- $\gamma)$ & NM_002090.1 & 8.67 \\
\hline IL-6 & NM_000600.1 & 8.63 \\
\hline Toll-like receptor 10 & NM_030956.1 & 7.78 \\
\hline Caveolin 2 & NM_001233.2 & 6.61 \\
\hline CCL13 (MCP-4) & NM_005408.2 & 4.85 \\
\hline MMP-25 & NM_022468.3 & 4.51 \\
\hline Caveolin-1 & NM_001753.3 & 4.42 \\
\hline CCL15 (Leukotactin-1) & NM_004167.2 & 4.32 \\
\hline TIMP-3 & NM_000362.3 & 3.99 \\
\hline CCL2 (MCP-1) & NM_002982.2 & 3.80 \\
\hline IL-16 & NM_172217.1 & 3.35 \\
\hline MMP-7 & NM_002423.2 & 3.35 \\
\hline IL-32 & NM_004221.2 & 3.02 \\
\hline SOD2 & NM_000636.1 & 3.02 \\
\hline
\end{tabular}

Human colonic subepithelial myofibroblasts were stimulated with IL-31 $(500 \mathrm{ng} / \mathrm{ml})$ for $12 \mathrm{~h}$, and the changes in gene expression were assessed by IntelliGene HS human expression chip (Takara-Bio). The fold change values were determined as a ratio of Cy5 signal intensity (IL-31stimulated values)/Cy 3 signal intensity (non-stimulated values). The data were the averages of three independent analyses. 

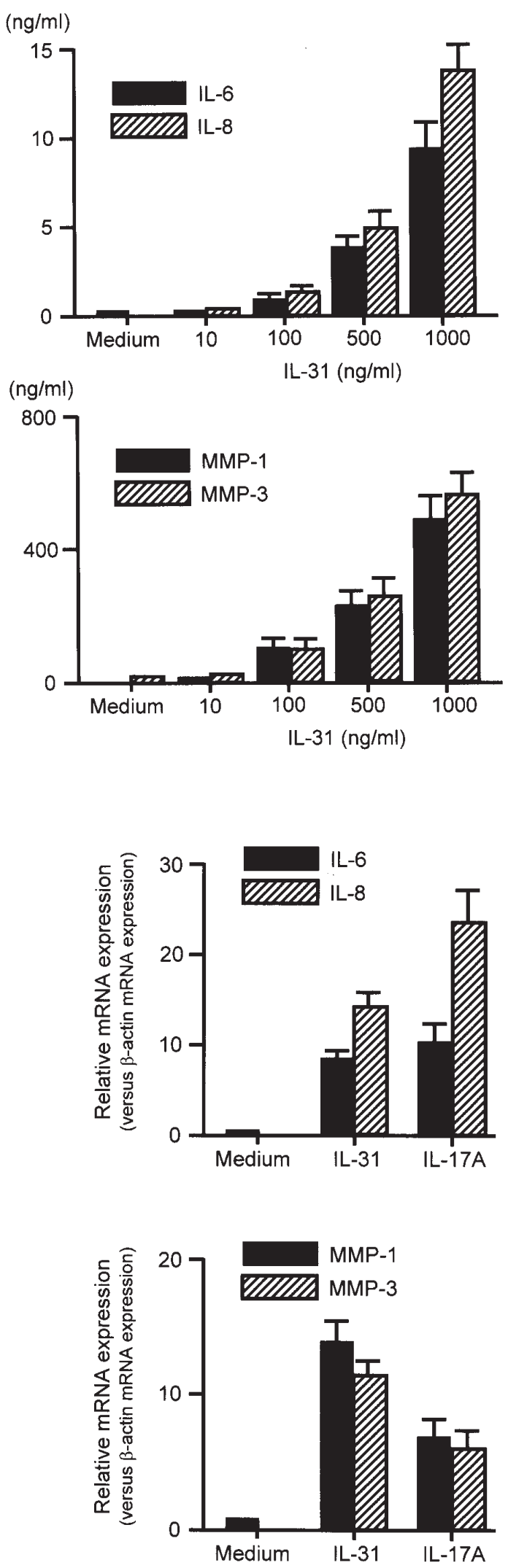

attractant protein-3; MCP-3), CXCL3, CCL13, and CCL15]; pro-inflammatory cytokines (IL-6, IL-16, and IL-32), and matrix metalloproteinases (MMP-1, MMP-3, MMP-25, and MMP-7).

Effects of IL-31 on secretion of cytokines, chemokines and MMPs. Among induced genes, we confirmed the effects of

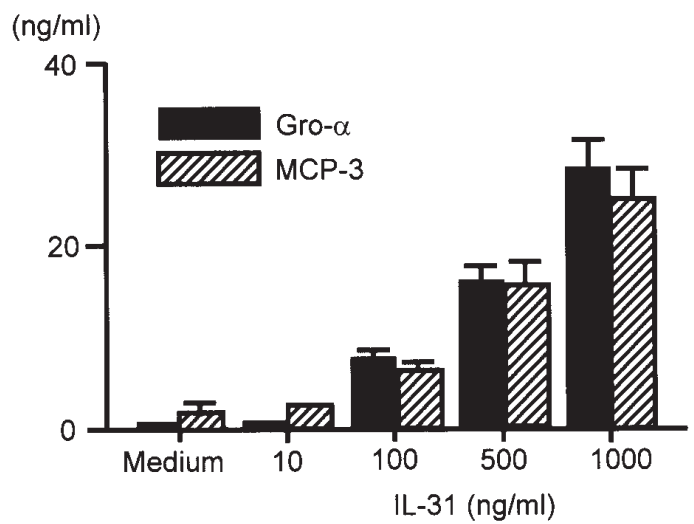

Figure 1. Effects of IL-31 on the secretion of IL-6, IL-8, GRO- $\alpha$, MCP-3, MMP-1 and MMP-3 protein in human colonic subepithelial myofibroblasts (SEMFs). Cells were incubated for $24 \mathrm{~h}$ with increasing concentrations of IL-31. The secreted cytokine levels were determined by ELISA. Values are expressed as means $\pm \operatorname{SD}(n=4)$.

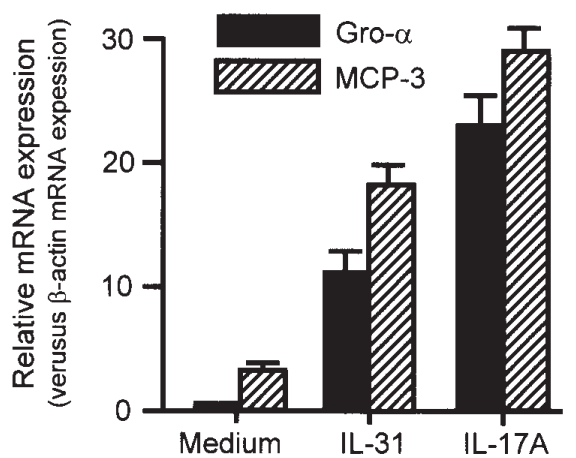

Figure 2. Comparison of IL-31 and IL-17A. Cells were incubated for $12 \mathrm{~h}$ with IL-31 (500 ng/ml) or IL-17A (500 ng/ml), and the mRNA expression of each gene was analyzed by real-time PCR. Data were normalized versus $ß$-actin for each gene. Values are expressed as means $\pm \operatorname{SD}(n=4)$.

IL-31 on secretion of IL-6, IL-8, GRO- $\alpha$, MCP-3, MMP-1 and MMP-3. As shown in Fig. 1, IL-31 dose-dependently induced secretion of these factors. Stimulatory effects of IL-31 were detectable at $100 \mathrm{ng} / \mathrm{ml}$.

Comparison of proinflammatory effects of IL-31 with effects of $I L-17 A$. Previously, we demonstrated that IL-17A, a 

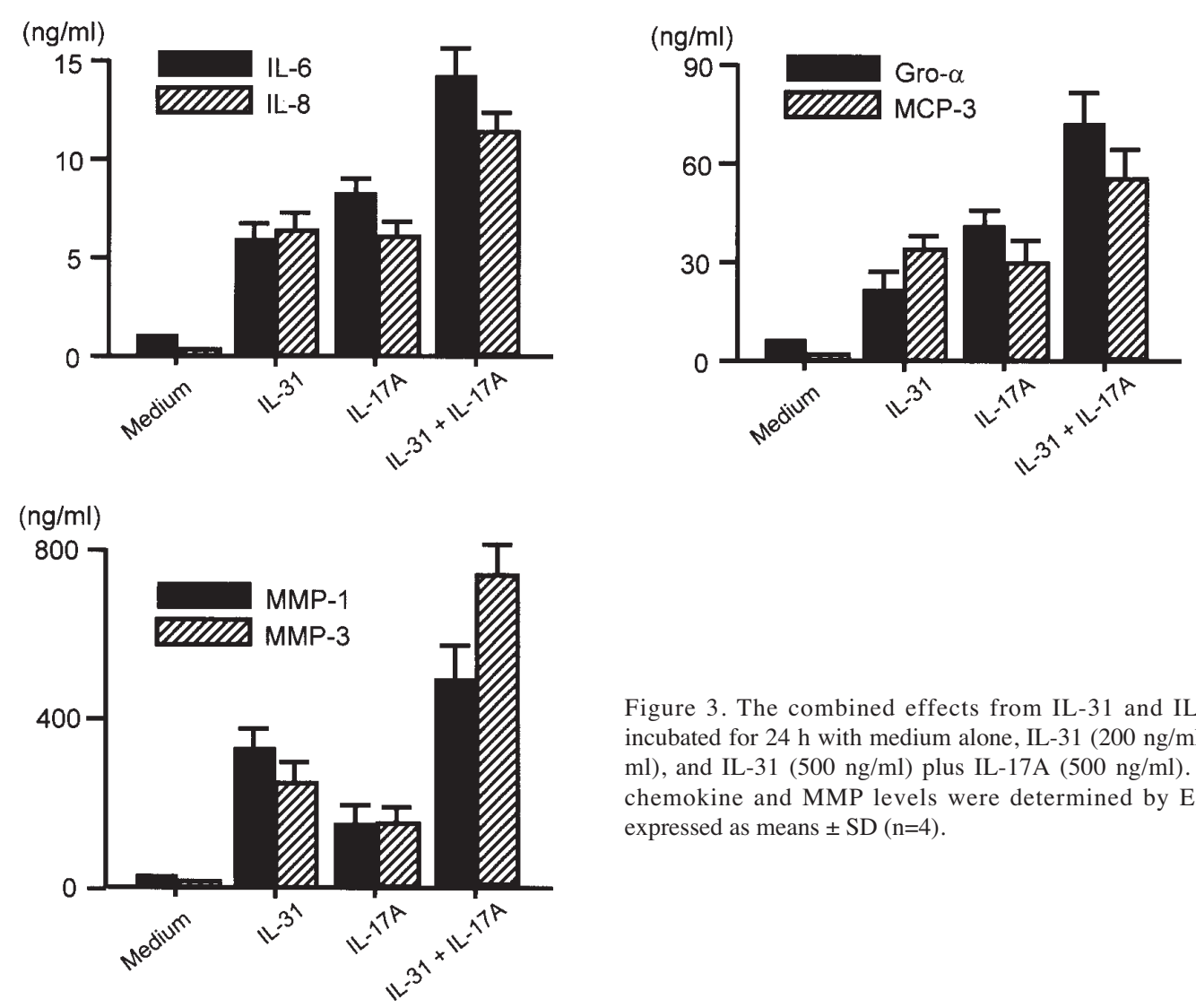

Figure 3. The combined effects from IL-31 and IL-17A. Cells were incubated for $24 \mathrm{~h}$ with medium alone, IL-31 $(200 \mathrm{ng} / \mathrm{ml})$, IL-17A (200 ng/ $\mathrm{ml})$, and IL-31 (500 ng/ml) plus IL-17A (500 ng/ml). Secreted cytokine, chemokine and MMP levels were determined by ELISA. Values are expressed as means $\pm \operatorname{SD}(n=4)$.

proinflammatory cytokine produced by $\mathrm{Th} 17 \mathrm{CD}^{+} \mathrm{T}$ cells (16), stimulated IL-6, IL-8 and MMP-3 secretion in human colonic SEMFs $(17,18)$. To compare the effects of IL-31 with those of IL-17A, we used the real-time PCR method. As shown in Fig. 2, IL-17A also induced the mRNA expression of IL-6, IL-8, GRO- $\alpha$, MCP-3, MMP-1 and MMP-3 in these cells. Stimulatory effects of IL-31 were comparable to the effects of IL-17A (Fig. 2).

Combination of IL-31 plus IL-17A. Next, we tested the combined effects of IL-31 and IL-17A in human colonic SEMFs. As shown in Fig. 3, simultaneous stimulation with IL-31 and IL-17A showed additive effects on IL-6, IL-8, GRO- $\alpha$, MCP-3, MMP-1 and MMP-3 secretion.

\section{Discussion}

Accumulating evidence indicates that IBD is a T-cell-mediated disease. For example, we previously reported an increase in the number of infiltrating $\mathrm{T}$ cells expressing IL-17 and/or IL-22 in IBD mucosa $(19,20)$. Mucosa-infiltrating effector $\mathrm{T}$ cells represent histopathological hallmarks of IBD, and $\mathrm{T}$ cell-derived cytokines play a crucial role in the pathophysiology of IBD.

Mice modified to overexpress IL-31 developed severe pruritis, alopecia and skin lesions, indicating the important immune functions of IL-31 in skin diseases. IL-31 is expressed by Th2 cells, and it signals through a heterodimeric receptor composed of GP130-like receptor (GPL) and oncostatin M receptor (OSMR), which is expressed on epithelial cells and keratinocytes $(4,21)$. IL-31 directly binds to GPL, and OSMR

mainly plays a role in the delivering of signaling information into cells. In response to IL-31, its receptor complex recruits Jak1, Jak2, STAT-1, STAT-3, and STAT5 signaling pathways, as well as the PI3-kinase/AKT cascade (21). SHP-2 and Shc adapter molecules are also recruited and contribute to an increased activation of the MAP kinase pathway in response to IL-31 (21). Despite the extensive study of intracellular signaling pathways activated by IL-31 stimulation, cellular responses to IL-31 have been scarcely investigated in any cell type. This may be due to a limited number of published reports concerning IL-31.

Sonkoly et al (36) previously demonstrated that GPL and OSMR are widely expressed in various tissues including the gastrointestinal tract. This suggests a role of IL-31 in immune and inflammatory responses in the intestine. In this study, we investigated how IL-31 modulates gene expression in human colonic SEMFs using cDNA microarray analyses, and found that IL-31 induces various genes which play major roles in the pathophysiology of IBD. We confirmed some of these responses by real-time PCR and ELISAs. Given the data presented herein, one hypothesis is that IL-31 is a proinflammatory cytokine derived from Th2 $\mathrm{T}$ cells.

IL-31 stimulated IL-6 gene expression in human colonic SEMFs. IL-6 is a pleiotropic cytokine with many pathophysiologic roles in humans (22). Its role in the pathophysiology of IBD was shown by the effects of anti-IL-6R antibodies to eliminate clinical symptoms of CD patients (23-25). IL-31 also up-regulated chemokine (IL-8, GRO- $\alpha$, GRO- $\gamma$, MCP-1, MCP-3, MCP-4, CCL-15) gene expression in colonic SEMFs. A histological feature of IBD is characterized by marked accumulation of inflammatory cells such as 
granulocytes and monocytes. IL-31 may contribute to granulocyte and monocyte accumulation in the intestinal mucosa via stimulation of chemokine secretion. Furthermore, IL-31 induced MMP (MMP-1, MM-3, MMP-7 and MMP-25) mRNA expression in these cells. MMPs are a family of calcium-dependent neutral proteases which orchestrate the developmental and homeostatic remodelling of the extracellular matrix (ECM) (26). ECM degradation is mainly dependent on the local release of MMPs, and increased secretion of MMPs results in tissue destruction. Collectively, these responses induced by IL-31 in human colonic SEMFs indicate that Th2 T cells may be involved in immune and inflammatory responses in intestinal mucosa through IL-31 secretion.

The IL-17 cytokine family is a recently discovered group of cytokines. IL-17A was originally cloned by Rouvier et al (27) and named CTLA8, subsequently renamed IL-17, and more recently IL-17A. IL-17A stimulates various cell types to secrete various cytokines and chemokines, resulting in the induction of inflammation (28-33). The IL-17 family may play a role in a number of diseases mediated by abnormal immune responses, such as rheumatoid arthritis $(34,35)$ and IBD (19). In this study, to characterize the inflammatory potential of IL-31, we compared proinflammatory effects of IL-31 with those of IL-17A. As shown in Fig. 2, IL-31 and IL-17A comparably induced proinflammatory genes in human colonic SEMFs. Furthermore, IL-31 and IL-17A additively stimulated secretion of proinflammatory mediators. Thus, Th2-derived IL-31 and Th17-derived IL-17A may cooperate in the pathophysiology of IBD.

In conclusion, we demonstrated that IL-31 is a potent inducer of proinflammatory mediators from human colonic SEMFs. To date, the pathological role of IL-31 was solely reported in the field of dermatology. However, our findings presented in this study suggest a role of IL-31 in the inflammatory responses of the intestine. Further investigations to analyze IL-31 functions are required to identify the role of IL-31 in the pathogenesis of IBD.

\section{References}

1. Podolsky DK: Inflammatory bowel disease. N Engl J Med 347: 417-429, 2002.

2. Hibi $\mathrm{T}$ and Ogata $\mathrm{H}$ : Novel pathophysiological concepts of inflammatory bowel disease. J Gastroenterol 41: 10-16, 2006.

3. Loftus EV Jr: Clinical epidemiology of inflammatory bowel disease: Incidence, prevalence, and environmental influences. Gastroenterology 126: 1504-1517, 2004.

4. Dillon SR, Sprecher C, Hammond A, Bilsborough J, Rosenfeld-Franklin M, Presnell SR, Haugen HS, Maurer M, Harder B, Johnston J, Bort S, Mudri S, Kuijper JL, Bukowski T, Shea P, Dong DL, Dasovich M, Grant FJ, Lockwood L, Levin SD, LeCiel C, Waggie K, Day H, Topouzis S, Kramer J, Kuestner R, Chen Z, Foster D, Parrish-Novak J and Gross JA: Interleukin 31 , a cytokine produced by activated $\mathrm{T}$ cells, induces dermatitis in mice. Nat Immunol 5: 752-760, 2004.

5. Heinrich PC, Behrmann I, Muller-Newen G, Schaper F and Graeve L: Interleukin-6-type cytokine signalling through the gp130/Jak/STAT pathway. Biochem J 334: 297-314, 1998.

6. Ghilardi N, Li J, Hongo JA, Yi S, Gurney A and de Sauvage FJ: A novel type I cytokine receptor is expressed on monocytes, signals proliferation, and activates STAT-3 and STAT-5. J Biol Chem 277: 16831-16836, 2002.

7. Andoh A, Bamba S, Fujiyama Y, Brittan M and Wright NA: Colonic subepithelial myofibroblasts in mucosal inflammation and repair: contribution of bone marrow-derived stem cells to the gut regenerative response. J Gastroenterol 40: 1089-1099, 2005.
8. Powell DW, Mifflin RC, Valentich JD, Crowe SE, Saada JI and West AB: Myofibroblasts. II. Intestinal subepithelial myofibroblasts. Am J Physiol 277: C183-C201, 1999.

9. Mahida YR, Beltinger J, Makh S, Goke M, Gray T, Podolsky DK and Hawkey CJ: Adult human colonic subepithelial myofibroblasts express extracellular matrix proteins and cyclooxygenase-1 and -2. Am J Physiol 273: G1341-G1348, 1997.

10. Powell DW, Mifflin RC, Valentich JD, Crowe SE, Saada JI and West AB: Myofibroblasts. I. Paracrine cells important in health and disease. Am J Physiol 277: C1-C9, 1999.

11. Okuno T, Andoh A, Bamba S, Araki Y, Fujiyama Y, Fujiyama M and Bamba T: Interleukin-1beta and tumor necrosis factor-alpha induce chemokine and matrix metalloproteinase gene expression in human colonic subepithelial myofibroblasts. Scand J Gastroenterol 37: 317-324, 2002.

12. Frederiksen CM, Aaboe M, Dyrskjot L, Laurberg S, Wolf H, Orntoft TF and Kruhoffer M: Technical evaluation of cDNA microarrays. APMIS Suppl: 96-101, 2003.

13. Chomczynski P and Sacchi N: Single-step method of RNA isolation by acid guanidinium thiocyanate-phenol-chloroform extraction. Anal Biochem 162: 156-159, 1987.

14. Andoh A, Fujiyama Y, Sumiyoshi K, Sakumoto H and Bamba T: Interleukin 4 acts as an inducer of decay-accelerating factor gene expression in human intestinal epithelial cells. Gastroenterology 111: 911-918, 1996

15. Strausberg RL, Feingold EA, Grouse LH, Derge JG, Klausner RD, Collins FS, Wagner L, Shenmen CM, Schuler GD, Altschul SF, Zeeberg B, Buetow KH, Schaefer CF, Bhat NK, Hopkins RF, Jordan H, Moore T, Max SI, Wang J, Hsieh F, Diatchenko L, Marusina K, Farmer AA, Rubin GM, Hong L, Stapleton M, Soares MB, Bonaldo MF, Casavant TL, Scheetz TE, Brownstein MJ, Usdin TB, Toshiyuki S, Carninci P, Prange C, Raha SS, Loquellano NA, Peters GJ, Abramson RD, Mullahy SJ, Bosak SA, McEwan PJ, McKernan KJ, Malek JA, Gunaratne PH, Richards S, Worley KC, Hale S, Garcia AM, Gay LJ, Hulyk SW, Villalon DK, Muzny DM, Sodergren EJ, Lu X, Gibbs RA, Fahey J, Helton E, Ketteman M, Madan A, Rodrigues S, Sanchez A, Whiting M, Madan A, Young AC, Shevchenko Y, Bouffard GG, Blakesley RW, Touchman JW, Green ED, Dickson MC, Rodriguez AC, Grimwood J, Schmutz J, Myers RM, Butterfield YS, Krzywinski MI, Skalska U, Smailus DE, Schnerch A, Schein JE, Jones SJ and Marra MA: Generation and initial analysis of more than 15,000 full-length human and mouse cDNA sequences. Proc Natl Acad Sci USA 99: 16899-16903, 2002.

16. Harrington LE, Hatton RD, Mangan PR, Turner H, Murphy TL, Murphy KM and Weaver CT: Interleukin 17-producing CD4+ effector $\mathrm{T}$ cells develop via a lineage distinct from the T helper type 1 and 2 lineages. Nat Immunol 6: 1123-1132, 2005.

17. Bamba S, Andoh A, Yasui H, Araki Y, Bamba T and Fujiyama Y: Matrix metalloproteinase-3 secretion from human colonic subepithelial myofibroblasts: role of interleukin-17. J Gastroenterol 38: 548-554, 2003.

18. Hata K, Andoh A, Shimada M, Fujino S, Bamba S, Araki Y, Okuno T, Fujiyama Y and Bamba T: IL-17 stimulates inflammatory responses via NF-kappaB and MAP kinase pathways in human colonic myofibroblasts. Am J Physiol Gastrointest Liver Physiol 282: G1035-G1044, 2002.

19. Fujino S, Andoh A, Bamba S, Ogawa A, Hata K, Araki Y, Bamba $T$ and Fujiyama Y: Increased expression of interleukin 17 in inflammatory bowel disease. Gut 52: 65-70, 2003.

20. Andoh A, Zhang Z, Inatomi O, Fujino S, Deguchi Y, Araki Y, Tsujikawa T, Kitoh K, Kim-Mitsuyama S, Takayanagi A, Shimizu N and Fujiyama Y: Interleukin-22, a member of the IL-10 subfamily, induces inflammatory responses in colonic subepithelial myofibroblasts. Gastroenterology 129: 969-984, 2005.

21. Diveu C, Lak-Hal AH, Froger J, Ravon E, Grimaud L, Barbier F, Hermann J, Gascan H and Chevalier S: Predominant expression of the long isoform of GP130-like (GPL) receptor is required for interleukin-31 signaling. Eur Cytokine Netw 15: 291-302, 2004.

22. Papanicolaou DA, Wilder RL, Manolagas SC and Chrousos GP: The pathophysiologic roles of interleukin-6 in human disease. Ann Intern Med 128: 127-137, 1998

23. Ito H, Takazoe M, Fukuda Y, Hibi T, Kusugami K, Andoh A, Matsumoto T, Yamamura T, Azuma J, Nishimoto N, Yoshizaki K, Shimoyama T and Kishimoto T: A pilot randomized trial of a human anti-interleukin-6 receptor monoclonal antibody in active Crohn's disease. Gastroenterology 126: 989-996, 2004. 
24. Ito $\mathrm{H}$, Hirotani T, Yamamoto $\mathrm{M}$, Ogawa $\mathrm{H}$ and Kishimoto T: Anti-IL-6 receptor monoclonal antibody inhibits leukocyte recruitment and promotes T-cell apoptosis in a murine model of Crohn's disease. J Gastroenterol 37 (suppl 14): 56-61, 2002.

25. Ito H: Treatment of Crohn's disease with anti-IL-6 receptor antibody. J Gastroenterol 40 (suppl 16): 32-34, 2005.

26. Nagase $\mathrm{H}$ and Woessner JF Jr: Matrix metalloproteinases. J Biol Chem 274: 21491-21494, 1999.

27. Rouvier E, Luciani MF, Mattei MG, Denizot F and Golstein P: CTLA-8, cloned from an activated T cell, bearing AU-rich messenger RNA instability sequences, and homologous to a herpesvirus saimiri gene. J Immunol 150: 5445-5456, 1993.

28. Kolls JK and Linden A: Interleukin-17 family members and inflammation. Immunity 21: 467-476, 2004.

29. Yao Z, Painter SL, Fanslow WC, Ulrich D, Macduff BM, Spriggs MK and Armitage RJ: Human IL-17: a novel cytokine derived from T cells. J Immunol 155: 5483-5486, 1995.

30. Fossiez F, Djossou O, Chomarat P, Flores-Romo L, Ait-Yahia S, Maat C, Pin JJ, Garrone P, Garcia E, Saeland S, Blanchard D, Gaillard C, Das Mahapatra B, Rouvier E, Golstein P, Banchereau $J$ and Lebecque S: T cell interleukin-17 induces stromal cells to produce proinflammatory and hematopoietic cytokines. J Exp Med 183: 2593-2603, 1996.

31. Yao Z, Fanslow WC, Seldin MF, Rousseau AM, Painter SL, Comeau MR, Cohen JI and Spriggs MK: Herpesvirus Saimiri encodes a new cytokine, IL-17, which binds to a novel cytokine receptor. Immunity 3: 811-821, 1995.
32. Jovanovic DV, Di Battista JA, Martel-Pelletier J, Jolicoeur FC, He Y, Zhang M, Mineau F and Pelletier JP: IL-17 stimulates the production and expression of proinflammatory cytokines, IL-beta and TNF-alpha, by human macrophages. J Immunol 160: 3513-3521, 1998.

33. Kawaguchi M, Adachi M, Oda N, Kokubu F and Huang SK: IL-17 cytokine family. J Allergy Clin Immunol 114: 1265-1273, 2004.

34. Kotake S, Udagawa N, Takahashi N, Matsuzaki K, Itoh K, Ishiyama S, Saito S, Inoue K, Kamatani N, Gillespie MT, Martin TJ and Suda T: IL-17 in synovial fluids from patients with rheumatoid arthritis is a potent stimulator of osteoclastogenesis. J Clin Invest 103: 1345-1352, 1999.

35. Ziolkowska M, Koc A, Luszczykiewicz G, Ksiezopolska-Pietrzak K, Klimczak E, Chwalinska-Sadowska H and Maslinski W: High levels of IL-17 in rheumatoid arthritis patients: IL-15 triggers in vitro IL-17 production via cyclosporin A-sensitive mechanism. J Immunol 164: 2832-2838, 2000.

36. Sonkoly E, Muller A, Lauerma AI, Pivarcsi A, Soto H, Kemeny L, Alenius H, Dieu-Nosjean MC, Meller S, Rieker J, Steinhoff M, Hoffmann TK, Ruzicka T, Zlotnik A, Homey B: IL-31: a new link between $\mathrm{T}$ cells and pruritus in atopic skin inflammation. $\mathrm{J}$ Allergy Clin Immunol 117: 411-417, 2006. 